\title{
Distribution of Batrachochytrium dendrobatidis and pathology in the skin of green tree frogs Litoria caerulea with severe chytridiomycosis
}

\author{
Lee Berger $^{1, *}$, Rick Speare ${ }^{1}$, Lee F. Skerratt ${ }^{2}$ \\ ${ }^{1}$ Amphibian Disease Ecology Group, School of Public Health, Tropical Medicine and Rehabilitation Sciences, \\ James Cook University, Townsville, Queensland 4811, Australia \\ ${ }^{2}$ Amphibian Disease Ecology Group, School of Veterinary and Biomedical Sciences, James Cook University, Townsville, \\ Queensland 4811, Australia
}

\begin{abstract}
Although histopathology is used routinely for diagnosis of chytridiomycosis in live and dead amphibians, there are no quantitative data on the distribution of the causative fungus, Batrachochytrium dendrobatidis, in the skin. We performed quantitative histological examinations on 6 sites on the body and 4 toes of 10 free-ranging adult green tree frogs Litoria caerulea found recently dead or dying from chytridiomycosis. Large numbers of sporangia occurred in all areas of ventral skin and toes; on average there were 94.3 sporangia $\mathrm{mm}^{-1}$ of superficial epidermis. The number of sporangia was highly variable and this appeared to be related to the stage in the cycle of sloughing. The stratum corneum tends to build up with high intensities of infection and then sheds entirely rather than being shed continuously. Very few or no sporangia occurred on dorsal skin. This distribution could be explained by the dryness of the dorsal skin or possibly by the greater number of serous glands, which produce antifungal peptides, on the dorsum. In some frogs, ulceration and erosions occurred on skin on the back in the absence of sporangia. Other pathological changes such as hyperkeratosis and congestion occurred much more frequently on ventral surfaces.
\end{abstract}

KEY WORDS: Batrachochytrium dendrobatidis · Distribution · Amphibian · Pathology · Ulceration • Litoria caerulea

Resale or republication not permitted without written consent of the publisher

\section{INTRODUCTION}

The histological appearance of Batrachochytrium dendrobatidis, associated histopathology, and details on how to use histology for diagnosis have been described (Berger et al. 1998, 2000, Pessier et al. 1999). On histologic examination, sporangia of $B$. dendrobatidis are seen in the superficial epidermis and occur in the stratum granulosum and stratum corneum (Berger et al. 1998, Pessier et al. 1999).

Skin lesions are often mild, with hyperkeratosis being the most obvious change. Bacteria often colonise the layers of sloughing keratin and grow within depleted sporangia. Other lesions include irregular multifocal epidermal hyperplasia, disor- dered epidermal cell layers, spongiosis, erosions and occasional ulcerations of the skin (Berger et al. 1998, Pessier et al. 1999, Berger 2001). An increase in the number of epidermal mitotic figures may be seen (Davidson et al. 2003). The usually smooth surface becomes roughened and irregular. The width of the epidermis is highly variable with diffuse or focal thickening in some areas, as well as large areas of thinning (Berger 2001). In some frogs, only a thin layer of 1 or 2 cells remains. Hypertrophic epidermal cells are evident in some frogs.

Individual epidermal cell necrosis is commonly seen in scattered cells in the stratum basale or stratum spinosum. These cells have pyknotic nuclei and pale swollen cytoplasm. Occasionally vacuolated degener- 
ate cells appear to coalesce into vesicles that resulted in lifting of the epidermis and ulceration (Berger 2001). This ballooning degeneration and cleavage occurs in the suprabasilar layer or between the dermis and epidermis. Some frogs have extensive ulceration, leaving the basement membrane exposed. In these frogs, infection is lost with the epidermis and only a few sporangia can be found.

There is usually only a mild inflammatory response, which may occur as a slight increase in mononuclear cells in the dermis. Foci of lymphocytes, macrophages and a few neutrophils sometimes occur in the superficial dermis, particularly in areas of ulceration. Occasional inflammatory cells are seen in the epidermis (Pessier et al. 1999).

In light infections in clinically normal amphibians in which a single focus of organisms may be found in a section, the hyperkeratosis was often confined to that focus, while in fatal infections, hyperkeratosis was usually widespread as were organisms (Berger 2001).

The fungus is unevenly distributed on the surface of the body; however, quantitative studies have not been reported. It was found most often in stratum corneum of the digits and ventral surfaces (especially the thighs and inguinal region) and less often on the dorsal surface (Berger et al. 1998, Pessier et al. 1999). The digits are recommended as a sensitive site to sample for diagnosis and have been used to conduct prevalence surveys of live wild frogs (Berger et al. 2000, Bonaccorso et al. 2003, Retallick et al. 2004, Weldon et al. 2004, McDonald et al. 2005).

The present study quantifies the distribution of zoosporangia of Batrachochytrium dendrobatidis and histopathological changes of the skin of green tree frogs Litoria caerulea that were severely ill or dead from chytridiomycosis.
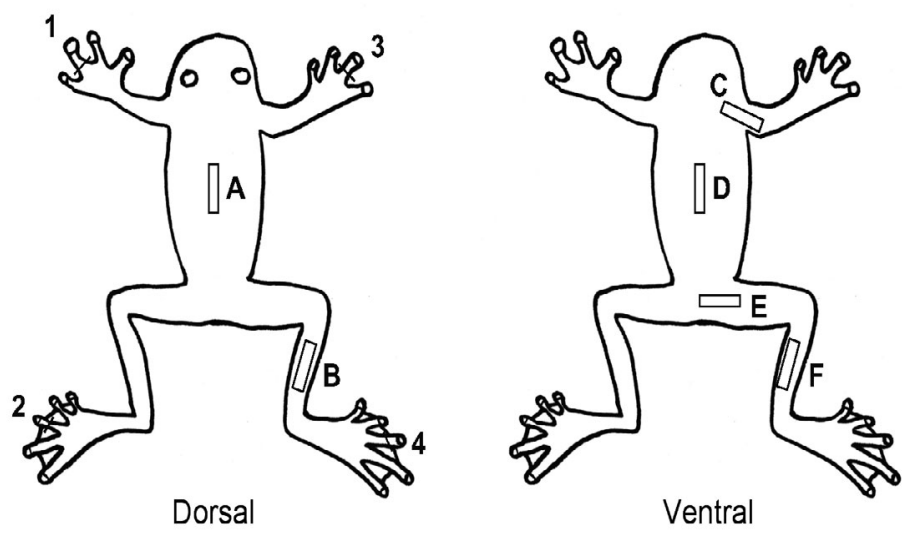

Fig. 1. Litoria caerulea. Sites on dorsal and ventral body and toes that were sampled to determine the distribution of infection, presence of pathology and abundance of skin glands

\section{MATERIALS AND METHODS}

The distribution of zoosporangia of Batrachochytrium dendrobatidis was studied in 10 wild Litoria caerulea with severe chytridiomycosis. This species was chosen as it is commonly found dying with chytridiomycosis in the wild. These frogs died in Queensland or northern New South Wales in winter. Nine female frogs and 1 male frog that were euthanized or died from chytridiomycosis were preserved in $10 \%$ buffered neutral formalin immediately after death. They had a mean snout-vent-length (s-v-l) of $78.2 \mathrm{~mm}$ $\pm 20.0 \mathrm{SD}$ (range 43 to $109 \mathrm{~mm}$ ) and were all in reasonable body condition. Strips of skin (approximately $3 \times$ $10 \mathrm{~mm}$ ) from 6 sites on the body (A to F in Fig. 1) were processed for histology and embedded longitudinally and perpendicularly so sections were transverse. A toe from each foot was cut at the start of the webbing and embedded to give a transverse section. A calibrated eyepiece micrometer was used to make a variety of measurements on $2.5 \mathrm{~mm}$ long sections at the centre of each strip, including number of sporangia, and thickness of skin (Table 1). Presence of pathology in this section was noted. Inflammation in the dermis was recorded if there was a clear increase in the number of leucocytes, although this was not quantified. Due to ulceration, erosions and hyperplasia, thickness of the epidermis varied greatly within individuals, so range in thickness, rather than mean thickness is included in the results. The number of epidermal cells from the surface to the dermis was counted. Abundance of serous and mucous glands in the dermis was also recorded. For some toes, less than $2.5 \mathrm{~mm}$ of epidermal length was present, but at least $1 \mathrm{~mm}$ of skin was counted for each toe. Ten sites on 2 healthy control adult frogs were also examined: a female (s-v-l: $96 \mathrm{~mm}$ ) and a male (s-v-l: $83 \mathrm{~mm}$ ). Sites were compared for significant differences using the Student's paired and non-paired 2 sample $t$-test 2-tailed or an ANOVA single factor test using Microsoft Excel. The correlation between number of sporangia and thickness of stratum corneum was performed using Pearson's coefficient of product moment correlation on SPSS, for Windows 6.1 (SPSS). Differences were regarded as significant when $p<0.05$. Internal organs were also examined for histopathology.

\section{RESULTS}

Signs of terminal chytridiomycosis in all Litoria caerulea were erythema of ventral skin and congestion of internal organs. Three of the 10 frogs had small ulcers grossly visible; 1 frog had four $3 \times 1 \mathrm{~mm}$ ulcers on the dorsal tibia, 1 had a small ulcer $(1 \times 1 \mathrm{~mm})$ on the 
Table 1. Batrachochytrium dendrobatidis infecting Litoria caerulea. Percentage of infected body sites and mean numbers of sporangia of $B$. dendrobatidis $\mathrm{mm}^{-1}$ skin section, and thickness of skin at 10 sites on the body of 10 wild green tree frogs with naturally acquired severe chytridiomycosis. See Fig. 1 for position of site on body. Values in parentheses are SD

\begin{tabular}{|c|c|c|c|c|c|c|c|c|c|c|}
\hline & \multicolumn{2}{|c|}{ Dorsal sites } & \multicolumn{4}{|c|}{ - Ventral sites - } & \multicolumn{4}{|c|}{ - Toes } \\
\hline & A & B & $\mathrm{C}$ & $\mathrm{D}$ & E & $\mathrm{F}$ & 1 & 2 & 3 & 4 \\
\hline Sporangia & 10 & 40 & 100 & 100 & 100 & 100 & 100 & 100 & 100 & 100 \\
\hline $\begin{array}{l}\text { Mean no. sporangia } \mathrm{mm}^{-1} \text { skin } \\
\text { surface at infected sites }\end{array}$ & 15 & $\begin{array}{c}12.2 \\
(10.4)\end{array}$ & $\begin{array}{c}98.4 \\
(74.04)\end{array}$ & $\begin{array}{c}92.4 \\
(98.80)\end{array}$ & $\begin{array}{c}95.2 \\
(63.92)\end{array}$ & $\begin{array}{c}49.6 \\
(27.88)\end{array}$ & $\begin{array}{c}96.8 \\
(51.00)\end{array}$ & $\begin{array}{c}113.2 \\
(69.52)\end{array}$ & $\begin{array}{c}118.0 \\
(101.32)\end{array}$ & $\begin{array}{c}90.8 \\
(74.48)\end{array}$ \\
\hline Hyperkeratosis & 10 & 20 & 100 & 90 & 80 & 80 & 100 & 100 & 100 & 90 \\
\hline Congestion & 0 & 60 & 100 & 60 & 70 & 60 & 80 & 100 & 100 & 90 \\
\hline Ulceration & 30 & 50 & 80 & 90 & 60 & 30 & 70 & 90 & 90 & 90 \\
\hline Erosions & 30 & 60 & 100 & 100 & 80 & 60 & 90 & 100 & 100 & 100 \\
\hline Inflammation in dermis & 10 & 20 & 20 & 20 & 30 & 10 & 40 & 20 & 40 & 30 \\
\hline Thickness of stratum corneum $(\mu \mathrm{m})$ & $\begin{array}{c}3.25 \\
(1.68)\end{array}$ & $\begin{array}{l}2.75 \\
(0.80)\end{array}$ & $\begin{array}{l}12.0 \\
(8.00)\end{array}$ & $\begin{array}{l}10.0 \\
(6.75)\end{array}$ & $\begin{array}{l}11.0 \\
(8.00)\end{array}$ & $\begin{array}{c}9.25 \\
(9.50)\end{array}$ & & & & \\
\hline Thickness of dermis $(\mu \mathrm{m})$ & $\begin{array}{l}363.75 \\
(98.78)\end{array}$ & $\begin{array}{c}381.25 \\
(127.05)\end{array}$ & $\begin{array}{l}245.75 \\
(62.45)\end{array}$ & $\begin{array}{c}291.5 \\
(91.43)\end{array}$ & $\begin{array}{c}223.75 \\
(105.55)\end{array}$ & $\begin{array}{l}195.25 \\
(55.78)\end{array}$ & & & & \\
\hline
\end{tabular}

thigh, and 1 had multiple $\sim 3 \mathrm{~mm}$ ulcers on the skin of the back, urostyle and tibio-tarsal joints.

\section{Distribution of infection}

Examination of skin from different sites of the body (Fig. 1) of 10 Litoria caerulea revealed that very few sporangia occurred on dorsal sites (Table 1). Sporangia occurred in only 1 frog on the back (Site A), but occurred in 4 frogs on the dorsal skin over the hindlimb (Site B). Heavy infections of sporangia occurred in all frogs at other sites, but numbers were highly variable and no significant differences were noted in the number of sporangia on ventral surfaces (Sites C, D, and E), and on toes ( $p>0.05)$. Site F on the medial hindlimb had a lower mean number of sporangia compared with ventral sites, and the difference was significant when compared with Sites $\mathrm{C}$ and $\mathrm{E}$ but not with D. Few sporangia remained in areas with microscopic ulceration in ventral sites, and this added to the variability of the results.

\section{Distribution of pathological changes}

Pathological changes were less common on skin of the back (Site A), although microscopic ulceration was present in $30 \%$ of frogs, occurring even in the absence of zoosporangia. At other sites ulceration was seen in 30 to $90 \%$ and erosions in 60 to $100 \%$ of frogs (Fig. 2). Congestion was not seen on the skin of the back but occurred in 60 to $100 \%$ of frogs at other sites that had dilated capillaries in the superficial dermis and tela subcutanea (the loose fibrous layer beneath the deep edge of the dermis).
Inflammation occurred in the dermis at 10 to $40 \%$ of sites. This was usually a slight but diffuse increase in mononuclear cells in the dermis, or small foci of cells in the dermis below areas of ulceration. Thickness of the stratum corneum was moderately correlated with number of sporangia ( $\mathrm{r}=0.62 ; \mathrm{p}<0.001)$. Ulceration, erosions, hyperkeratosis, congestion and inflammation were not seen in uninfected control frogs.

Epidermal thickness was highly variable, ranging from a complete absence of epidermis in ulcerated areas, to a thin layer 2 or 3 cells thick, to relatively normal areas about 5 cells thick, to hyperplastic areas up to $125 \mu \mathrm{m}$ thick consisting of up to 13 layers of cells. In control frogs, the epidermis was smooth and even, ranging from 25 to $60 \mu \mathrm{m}$ and was always between 4 and 7 cells thick.

Thickness of the dermis was not significantly different to the controls $(p>0.05)$. The dermis was thicker on dorsal skin, and was thinner in smaller frogs.

Serous glands were more abundant in the 2 dorsal sites, with more on the hindlimb than the back; however, the size of serous glands varied greatly, with the largest ones occurring on the back. Serous glands also occurred at all ventral body sites and were present even in areas of heavy infection with sporangia. Serous glands were abundant in dorsal skin of the toes but not ventrally. Mucous glands were more evenly distributed over the body and differences between sites were not observed.

The distribution of the substantia amorpha was not quantified, but it was noted to occur more continuously and abundantly on dorsal skin, and was present on ventral skin of the belly and legs in a thinner and less consistent layer. It occurred on dorsal skin of the toes but not ventrally. 


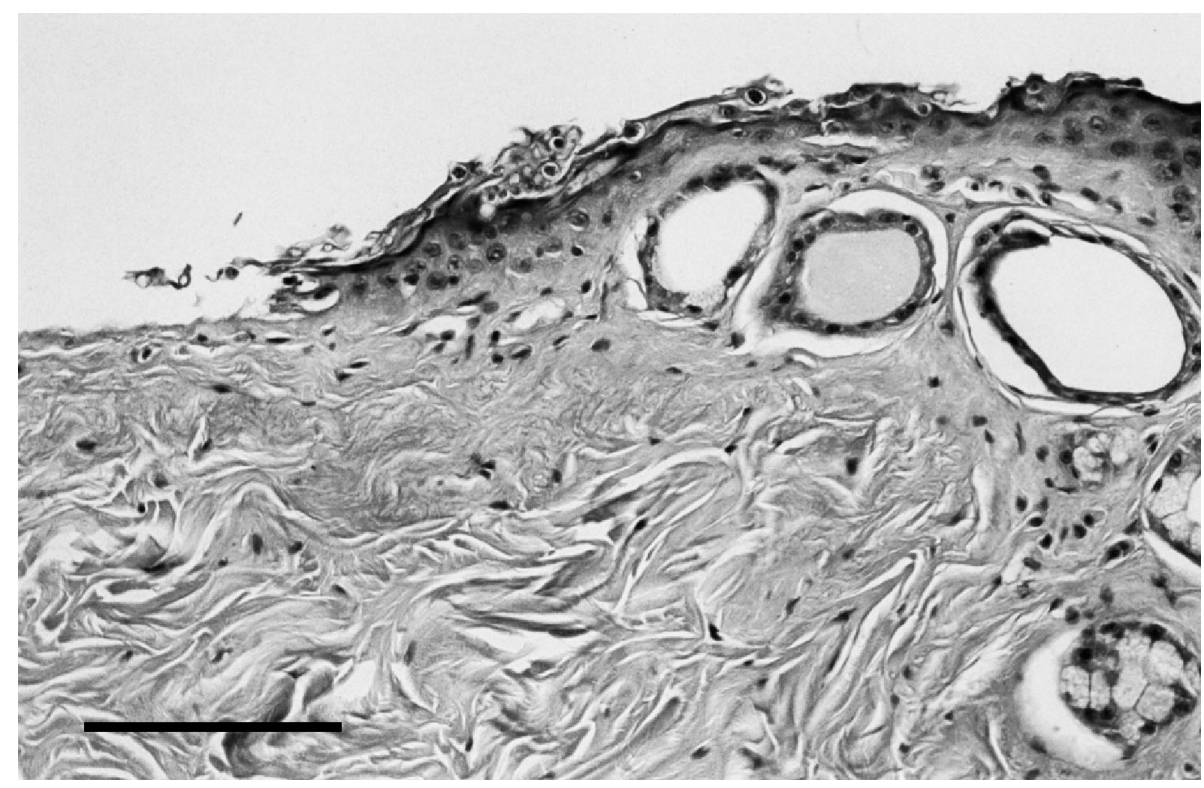

Fig. 2. Batrachochytrium dendrobatidis infecting Litoria caerulea. Histological section of the edge of an ulcer. The remaining epidermis is thin ( 2 to 5 cells thick). Scale bar $=90 \mu \mathrm{m}$. (H\&E)

\section{DISCUSSION}

In the study of distribution of infection in severely infected Litoria caerulea, large numbers of sporangia occurred in all areas of ventral skin examined. The number of sporangia was highly variable and this may be related to sloughing of the stratum corneum, and because sporangia were not present in ulcerated areas. Very few or no sporangia occurred at 2 sites of dorsal skin. This finding explains the low percentage of confirmed cases (62\%) of chytridiomycosis in the epidemic in rainforest frogs from Big Tableland, North Queensland in 1993 (Berger et al. 1998), since only skin from the back of dead and ill frogs was examined.

Large parotoid glands occur on dorsal skin behind the tympanum, and antifungal secretions from these glands or the smaller dispersed serous glands (which were more abundant in dorsal skin) may inhibit infection. However, sporangia were seen growing at the opening of ducts of serous glands, suggesting secretions are not effective in stopping infection. Skin peptides vary between amphibian species and even geographically within Litoria caerulea (Donnellan et al. 2000). The peptides are believed to cause cell death by disruption of the cell membrane into peptide-coated vesicles (Rollins-Smith et al. 2002b). A range of peptides from amphibian skin is active against Batrachochytrium dendrobatidis in vitro in a concentrationdependent manner (Rollins-Smith et al. 2002a). Even frogs that have declined, such as Rana tarahumarae, secrete peptides that inhibit growth of $B$. dendro- batidis in vitro (Rollins-Smith et al. 2002b). It is not clear why frogs with apparently effective antimicrobial peptide defences are susceptible to chytridiomycosis. The authors suggest there may not be enough peptides present on the skin to be effective, or that environmental factors that stress the frog may inhibit production or release of the peptides (Rollins-Smith et al. 2002b).

Three peptides (including synthetic caerin 1.1) found in dermal glands in Australian tree frogs that were tested on Batrachochytrium dendrobatidis inhibited zoospore encystment and growth at concentrations of $12.5 \mu \mathrm{g} \mathrm{ml} \mathrm{m}^{-1}$ (Berger 2001), but the concentration at which they occur naturally on skin is not known. Caerin 1.1 is the major peptide isolated from Litoria caerulea and has a broad antibacterial spectrum of activity (Bowie et al. 1999). A total of 40 peptides have so far been identified from skin secretions in $L$. caerulea (Bowie et al. 1999). Although the antifungal peptides are obviously not effective in protecting all $L$. caerulea from chytridiomycosis, they may be involved in differences in susceptibility of individuals and species.

Litoria caerulea was shown experimentally to be highly susceptible to chytridiomycosis compared with 3 other species (Ardipradja 2001). The pathology in $L$. caerulea does not appear representative of all frog species and differs in at least 2 aspects. Severe congestion consistently occurred in skin and internal organs, and ulceration appeared more commonly than in other species (L. Berger unpubl.). 
As with other species that have a substantia amorpha (Elkan 1968), the Litoria caerulea examined here also had a thicker layer in dorsal skin. This granular layer contains calcium and polysaccharides believed to prevent dehydration (Elkan 1968). The dermis of exposed dorsal skin is thicker, and the skin surface is presumably drier than the ventral skin that is used for water uptake. $L$. caerulea is a large xeric-adapted frog that can withstand dry conditions in arid Australia (Warburg et al. 2000). This species loses little water through evaporation (which may be partly due to lipid in the skin secretions) (Warburg et al. 2000) and so the back may remain dry. Many frogs rely on ventral skin for water absorption, and the regions where heavier infections occur are areas kept in contact with moist substrate.

As zoospores of Batrachochytrium dendrobatidis require water for dispersal, the dryness of dorsal skin in terrestrial frogs could explain the distribution of infection. This is supported by information that in the aquatic Xenopus tropicalis dorsal skin was infected as heavily as ventral skin (Parker et al. 2002). However, another explanation for the pattern of distribution is that the ventral surface may be more frequently exposed to $B$. dendrobatidis compared with dorsal surfaces. This may occur if $B$. dendrobatidis occurs most commonly on moist surfaces in the terrestrial environment and on substrates and not in the water column in the aquatic environment. Another fungal disease, epidermal infection of Bufo baxteri with Mucor sp., also occurred on ventral skin (Taylor et al. 1999).

Similar infection levels of sporangia of Batrachochytrium dendrobatidis were reported in toes from experimentally infected juvenile frogs (Ardipradja 2001). Litoria caerulea died with an average of 59.2 sporangia $\mathrm{mm}^{-1}$, while Mixophyes fasciolatus had a heavier burden of 95.5 sporangia $\mathrm{mm}^{-1}$ at the time of death.

Although ulceration and erosions occurred on skin on the back in the absence of sporangia, other pathological changes such as epidermal hyperplasia, hyperkeratosis and congestion occurred more in infected sites. The low percentage of sites with inflammation in skin could be due to a lack of stimulation of the host immune system, which may be due to the superficial site of infection or Batrachochytrium dendrobatidis may have low inherent antigenicity, or may inhibit the immune response. As sporangia occur in dense keratinising cells, perhaps this provides some protection from being detected by the immune response. In mammals, antibodies are not generated in response to dermatomycoses (ringworm), as the superficial epidermal infections do not stimulate antibody producing cells as occurs with systemic fungal infections (Carter 1986).
For diagnosis of Litoria caerulea with severe chytridiomycosis, we have confirmed that examination of skin from ventral surfaces or toes is preferable. However, this study should be repeated in healthy $L$. caerulea with light infections to confirm that the digits are sites of predilection in early infections.

Acknowledgements. Many thanks to H. B. Hines and J. Clarke for collection of ill frogs, and to M. Braun for preparation of histological slides. This work was supported by Environment Australia and the Australian Research Council.

\section{LITERATURE CITED}

Ardipradja K (2001) A study of resistance towards the emerging pathogen Batrachochytrium dendrobatidis in four species of Australian frogs. Honours thesis, University of Melbourne

Berger L (2001) Diseases in Australian frogs. PhD thesis, James Cook University, Townsville

Berger L, Speare R, Daszak P, Green DE and 10 others (1998) Chytridiomycosis causes amphibian mortality associated with population declines in the rain forests of Australia and Central America. Proc Natl Acad Sci USA 95: 9031-9036

Berger L, Speare R, Kent A (2000) Diagnosis of chytridiomycosis in amphibians by histologic examination. Zoos Print J 15:184-190. Also available at www.jcu.edu.au/school/ phtm/PHTM/frogs/histo/chhisto.htm

Bonaccorso E, Guayasamin JM, Méndez D, Speare R (2003) Chytridiomycosis in a Venezuelan amphibian (Bufonidae: Atelopus cruciger). Herpetol Rev 34:331-334

Bowie JH, Wegener KL, Chia BCS, Wabnitz PA, Carver JA, Tyler MJ, Wallace JC (1999) Host defence antibacterial peptides from skin secretions of Australian amphibians. The relationship between structure and activity. Protein Pept Letters 6:259-269

Carter GR (1986) Introduction to the fungi and fungus infections. In: Essentials of veterinary bacteriology and microbiology, 3rd edn. Lea \& Febiger, Philadelphia, PA, p 223-227

Davidson EW, Parris M, Collins JP, Longcore JE, Pessier AP, Brunner J (2003) Pathogenicity and transmission of chytridiomycosis in tiger salamanders (Ambystoma tigrinum). Copeia 2003:601-607

Donnellan SC, Tyler MJ, Monis P, Barclay A, Medlin A (2000) Do skin peptide profiles reflect speciation in the Australian treefrog Litoria caerulea (Anura: Hylidae)? Aust J Zool 48:33-46

Elkan E (1968) Mucopolysaccharides in the anuran defense against desiccation. J Zool (Lond) 155:19-53

McDonald KR, Méndez D, Müller R, Freeman AB, Speare R (2005) Decline in the prevalence of chytridiomycosis in upland frog populations in North Queensland, Australia. Pac Conserv Biol 11:114-120

Parker JM, Mikaelian I, Hahn N, Diggs HE (2002) Clinical diagnosis and treatment of epidermal chytridiomycosis in African clawed frogs (Xenopus tropicalis). Comp Med (Memphis) 52:265-268

Pessier AP, Nichols DK, Longcore JE, Fuller MS (1999) Cutaneous chytridiomycosis in poison dart frogs (Dendrobates spp.) and White's tree frogs (Litoria caerulea). J Vet Diagn Invest 11:194-199 
Retallick RW, McCallum H, Speare R (2004) Endemic infection of the amphibian chytrid fungus in a frog community post-decline. PLOS Biol 2:e351

Rollins-Smith LA, Carey C, Longcore J, Doersam JK, Boutte A, Bruzgal JE, Conlon JM (2002a) Activity of antimicrobial skin peptides from ranid frogs against Batrachochytrium dendrobatidis, the chytrid fungus associated with global amphibian declines. Dev Comp Immunol 26: 471-479

Rollins-Smith LA, Reinert LK, Miera V, Conlon JM (2002b) Antimicrobial peptide defenses of the Tarahumara frog,

Editorial responsibility: Peernel Zwart, Utrecht, The Netherlands
Rana tarahumarae. Biochem Biophys Res Comm 297: 361-367

Taylor SK, Williams ES, Pier AC, Mills KW, Bock MD (1999) Mucormycotic dermatitis in captive adult Wyoming toads. J Wildl Dis 35:70-74

Warburg MR, Rosenberg M, Roberts JR, Heatwole H (2000) Cutaneous glands in the Australian hylid Litoria caerulea (Amphibia, Hylidae). Anat Histol Embryol 201:341-348

Weldon C, du Preez LH, Hyatt AD, Muller R, Speare R (2004) Origin of the amphibian chytrid fungus. Emerg Infect Dis 10:2100-2105

Submitted: April 20, 2005; Accepted: June 22, 2005

Proofs received from author(s): October 19, 2005 